\title{
RANCANG BANGUN APLIKASI ABSENSI DAN PENGGAJIAN PADA KANTOR KPU MENGGUNAKAN FRAMEWORK LARAVEL (STUDI KASUS : KPU KABUPATEN BENGKALIS)
}

\author{
Uci Rahmalisa ${ }^{1}$, Arie Linarta ${ }^{2}$ \\ ${ }^{1}$ Sistem Informasi STMIK Hang Tuah Pekanbaru \\ Jl. Mustafa Sari No.5, 28288 Indonesia \\ ${ }^{2}$ Sistem Informasi STMIK Dumai \\ Jl. Utama Karya Bukit Batrem Dumai, 28811 Indonesia
}

Abstract-The Bengkalis KPU consists of several fields, one of which is the general field. One of the tasks that this general department manages is attendance and payroll. The attendance process at the Bengkalis Regency KPU office is carried out conventionally where employees who work at the Bengkalis Regency KPU office must sign the attendance column that is already available in the public section. For monthly attendance data, it is done at the end of each month which is inputted by the general operator in Microsoft Excel. The system development method used is the waterfall. At this stage there will be needs analysis, system design, coding using the PHP programming language and MySQL database, testing the program carried out, namely black box, and finally implementing the program. The conclusion obtained is the application for the process of attendance and payroll data recap, which previously only used the way to sign absences which was managed by the admin, then the admin would input the attendance data in Microsoft Excel and recap employees' salaries. This application has two parts, namely admin and employees (employees and honorary). Attendance and payroll applications at the KPU office can input employee, honorary and absent data which will result in a recap of attendance and payroll periodically (daily, monthly and yearly).

Abstrak - Di KPU Kabupaten Bengkalis terdiri dari beberapa bidang salah satunya yaitu bidang umum. Salah satu tugas yang dikelola bagian umum ini adalah absensi dan penggajian. Proses absensi di kantor KPU Kabupaten Bengkalis dilakukan secara konvensional dimana karyawan yang bekerja di kantor KPU Kabupaten Bengkalis harus menandatangani kolom absen kehadiran yang sudah tersedia di bagian umum. Untuk perekapan data absensi perbulan dilakukan setiap akhir bulan yang diinput oleh operator bagian umum di Microsoft Excel. Metode pengembangan sistem yang digunakan yaitu waterfall. Pada tahap ini akan dilakukan analisa kebutuhan, desain sistem, coding dengan menggunakan bahasa pemograman PHP dan database MySQL, pengujian program yang dilakukan yaitu black box, dan terakhir penerapan program. Kesimpulan yang diperoleh adalah aplikasi untuk proses rekap data absensi dan penggajian yang sebelumnya hanya menggunakan cara menandatangani absen yang dikelola admin kemudian admin akan menginput data absen di Microsoft Excel dan merekap gaji perkaryawan. Aplikasi ini memiliki dua bagian yaitu admin dan karyawan (pegawai dan honorer). Aplikasi Absensi dan Penggajian Pada Kantor KPU dapat melakukan penginputan data pegawai, honorer dan absen yang akan menghasilkan rekap absensi dan penggajian secara berkala (perhari,perbulan dan pertahun). Keywords - Absensi dan Peggajian, Framework, KPU, Laravel

\section{Pendahuluan}

Untuk menghadapi Pemilihan Umum, KPU harus dapat berfungsi secara efektif dan mampu memfasilitasi pelaksanaan pemilu yang jujur dan adil. Terlaksananya pemilu yang jujur dan adil tersebut merupakan faktor penting bagi terpilihnya wakil rakyat yang lebih berkualitas dan mampu menyuarakan aspirasi rakyat. Sebagai anggota KPU, integritas moral sebagai pelaksana pemilu sangat penting, selain menjadi motor penggerak KPU juga membuat KPU lebih kredibel di mata masyarakat karena didukung oleh personal yang jujur dan adil.
Untuk itu Komisi Pemilihan Umum Kabupaten Bengkalis juga memiliki tanggung jawab yang sama sehingga dituntut independen dan non partisan. Untuk melaksanakan Pemilihan Umum, KPU mempunyai tugas kewenangan yang dipertanggungjawabkan di setiap bidang. Di KPU Kabupaten Bengkalis terdiri dari beberapa bidang salah satunya yaitu bidang umum. Salah satu tugas yang dikelola bagian umum ini adalah absensi dan penggajian.

Proses absensi di kantor KPU Kabupaten Bengkalis dilakukan secara konvensional dimana karyawan yang bekerja di kantor KPU Kabupaten 
Bengkalis harus menandatangani kolom absen kehadiran yang sudah tersedia di bagian umum. Untuk perekapan data absensi perbulan dilakukan setiap akhir bulan yang diinput oleh operator bagian umum di Microsoft Excel. Sebelum proses penginputan, operator harus mengecek ulang kolom absensi yang sudah ditanda tangani oleh karyawan karena masih terdapat karyawan yang hadir namun tidak menandatangani absensi dan apabila ada absensi hilang, hal ini membuat admin harus bertanya kepada setiap karyawan untuk kehadirannya sehingga sering terjadi kekeliruan. Jika kolom belum terisi penuh selama sebulan maka operator belum dapat melakukan penginputan absen sehingga terjadinya penundaan perekapan data absensi.

Apabila perekapan data absensi tertunda maka untuk perekapan penggajian juga ikut tertunda. Untuk proses penggajian dilakukan berdasarkan kehadiran karyawan karena setiap potongan persen gaji karyawan berdasarkan keterangan kehadiran di absensi (Dinas, izin, sakit, cuti dan alfa).

Dari permasalahan diatas, maka peneliti ingin membuat aplikasi Absensi dan Penggajian Pada Kantor KPU Menggunakan Framework Laravel dan MySQL sebagai database. Aplikasi ini bertujuan untuk memudahkan admin untuk proses rekap data absensi dan penggajian, dan memudahkan karyawan untuk melihat hasil absensi setiap bulan. Pada aplikasi, admin hanya perlu mengisi data kehadiran setiap karyawan dengan menu-menu yang sudah tersedia dan dapat mencetak hasil rekapitulasi data absensi dan penggajian dengan mudah dan cepat, serta dengan adanya fungsi hitung penggajian otomatis yang membuat admin tidak perlu lagi menghitung gaji karyawan secara manual. Selain itu aplikasi Absensi dan Penggajian Pada Kantor KPU Menggunakan Framework Laravel memiliki beberapa fitur seperti mencetak data absensi dan penggajian setiap karyawan berdasarkan bulan. Beberapa permasalahan yang dihadapai diantaranya :

1. Sistem absensi dan penggajian karyawan yang sedang berjalan masih kurang efektif, sehingga mudah terjadi kecurangan dalam proses absensi dan penggajian karyawan.

2. Membutuhkan waktu yang lama untuk mencari atau menemukan data absensi dan penggajian karyawan, sehingga lambatnya untuk pelaporan penggajian.

3. Sulitnya menghitung gaji karyawan tanpa rekap absensi yang lengkap, sehingga terjadinya penundaan gaji karyawan.

\section{Metode Penelitian}

Model pengembangan sistem yang digunakan adalah model waterfall.

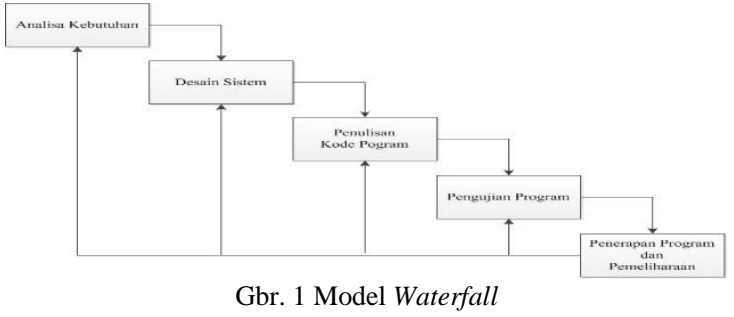

1. Analisa Kebutuhan. Pada tahap ini akan dilakukan analisa kebutuhan pelanggan terhadap sistem yang akan dibuat. Langkah yang dilakukan adalah dengan teknik wawancara. Setelah kebutuhan pengguna diidentifikasi, selanjutnya akan dilakukan observasi dan studi literatur terkait penelitian yang akan dilakukan.

2. Desain sistem. Pada proses Desain Sistem, dilakukan tahapan menganalisa gambaran seperti apa sistem yang akan dibuat, bagaimana interface untuk setiap kegiatannya, serta mendefinisikan arsitektur sistem secara keseluruhan.

3. Coding, Pengkodean merupakan proses penterjemahkan perancangan sistem kebentuk yang dapat dimengerti oleh mesin, dengan menggunakan bahasa pemrograman. Tahap inilah yang merupakan tahapan secara nyata dalam mengerjakan suatu sistem dalam artian penggunaan komputer akan dimaksimalkan dalam tahapan ini. Pada penelitian ini, coding dilakukan menggunakan Framework Laravel, bahasa pemograman PHP dan database MySQL.

4. Setelah proses pengkodeaan selesai dilanjutkan proses pengujian pada program perangkat lunak, baik pengujian logika internal, maupun pengujian eksternal fungsional untuk memeriksa segala kemungkinan terjadinya kesalahan dan memeriksa apakah hasil dari pengembangan tersebut sesuai dengan hasil yang diinginkan. Dimana sistem yang baru diuji kemampuan dan keefektifannya sehingga didapatkan kekurangan dan kelemahan sistem yang kemudian dilakukan pengkajian ulang dan perbaikan terhadap aplikasi menjadi lebih baik dan sempurna.

5. Penerapan Program, Perangkat lunak yang telah diuji dan diterima pelanggan dan siap digunakan. Model Protyping ini sangat sesuai diterapkan untuk kondisi yang beresiko tinggi dimana masalah-masalah tidak terstruktur dengan baik, terdapat fluktuasi kebutuhan pemakaian yang berubah dari waktu ke waktu atau tidak terduga, bila interaksi dengan pemakai menjadi syarat mutlak dan waktu tersedia sangat terbatas sehingga butuh penyelesaian yang segera. Program akan diterapkan di kantor Komisi Pemilihan Umum Kabupaten Bengkalis dan dilakukan pemeliharaan.

\section{Hasil}

Pada bagian ini akan diuraikan hasil dari penelitian : 


\section{A. Analisa sistem yang digunakan}

Pengolahan data Absensi dan penggajian masih menggunakan Ms. Exel dan proses perekap data yang dilakukan secara manual, yaitu dengan cara mengecek ulang satu persatu lembar absensi yang telah di tandatangani oleh karyawan yang bekerja di kantor KPU tersebut.

\section{B. Permasalahan dan Kendala}

Proses perekapan data Absensi masih dilakukan dengan cara konvensional, admin harus mengecek ulang satu persatu data absensi yang sudah ditandatangani oleh karyawan yang bekerja di kantor KPU berdasarkan tanggalnya, dilakukan pemeriksaan ulang data absensi tersebut untuk memastikan apakah data absensi sudah lengkap atau belum jika belum lengkap maka absensi tersebut belum bisa untuk di rekap. Hal ini membutuhkan waktu yang lama, sehingga memperlambat proses aliran data ke Kantor KPU tersebut.

\section{Alternatif Solusi Masalah}

Proses perekapan data Absensi masih dilakukan dengan cara konvensional, admin harus mengecek ulang satu persatu data absensi yang sudah ditandatangani oleh karyawan yang bekerja di kantor KPU berdasarkan tanggalnya, dilakukan pemeriksaan ulang data absensi tersebut untuk memastikan apakah data absensi sudah lengkap atau belum jika belum lengkap maka absensi tersebut belum bisa untuk di rekap. Hal ini membutuhkan waktu yang lama, sehingga memperlambat proses aliran data ke Kantor KPU tersebut.

Pegawai dan honorer yang bekerja di kantor KPU melakukan absensi dengan cara melaporkan diri kepada admin bahwa mereka hadir. Kemudian admin akan menginput data absen ke dalam aplikasi absensi dan penggajian. Selain menginput data absensi dan penggajian pada aplikasi, admin juga bisa melihat data absensi dan data penggajian, kemudian admin melakukan perekapan terhadap absensi dan juga gaji apabila absensi tersebut sudah penuh selama sebulan.

\section{1) Tampilan halaman login}

Berikut ini adalah tampilan Login pada Aplikasi Rancang Bangun Aplikasi Absensi dan Penggajian Menggunakan Framework Lravel.

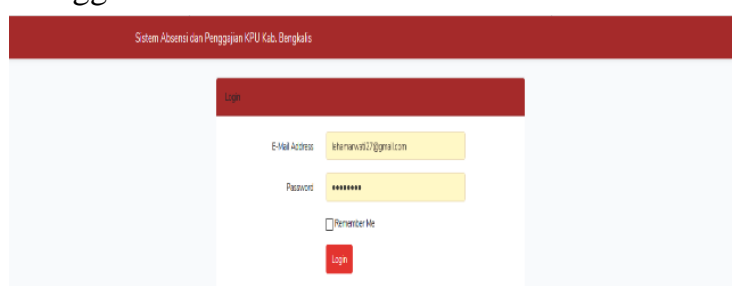

Gbr. 1 Tampilan Halaman Login

\section{2) Tampilan halaman administrator:}

a. Tampilan home administrator

Berikut ini adalah tampilan Home Administrator pada Aplikasi Rancang Bangun Aplikasi Penggajian Menggunakan Farmework Laravel.

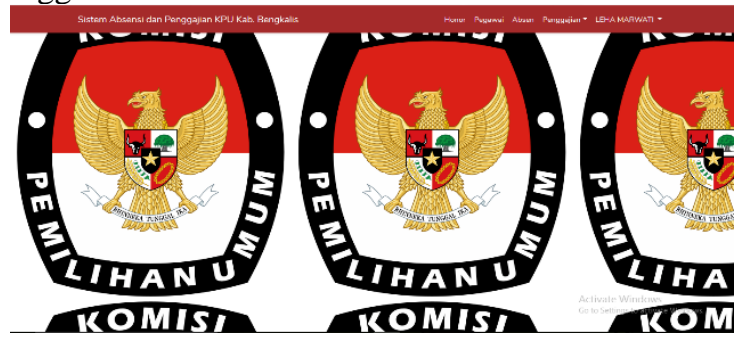

Gbr. 2 Tampilan Halaman Home Administrator

Gambar di atas tampilan halaman home administrator yang merupakan tampilan setelah halaman login dari Aplikasi. Pada menu ini terdapat menu Honor, Pegawai, Absen, Penggajian, dan menu logout.

b. Tampilan menu honor, berikut ini merupakan tampilan karyawan honot kantor KPU.

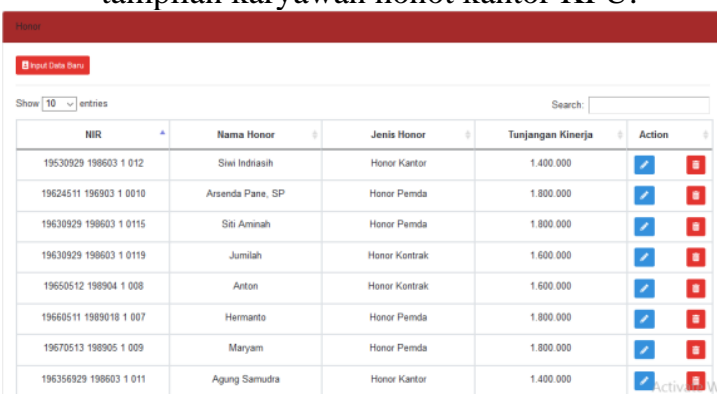

Gbr. 3 Tampilan Menu Honor

c. Tampilan menu input honor, Tampilan menu input honor terdapat form biodata honorer yang harus diinput oleh admin, terdiri dari form NIR, Nama Honor, Jenis Honor dan Tunjangan Kinerja.

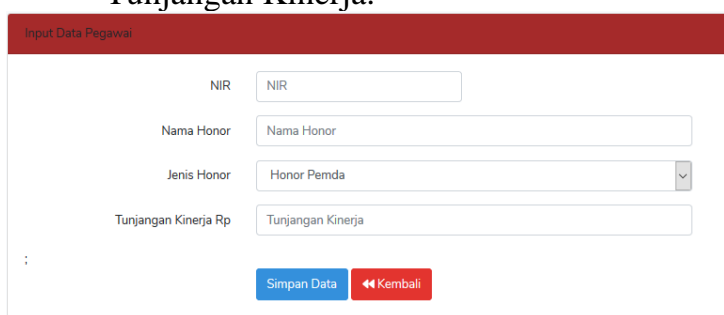

Gbr. 4 Tampilan Menu Input Honor

d. Tampilan Menu Pegawai, Tampilan menu pegawai ini menampilkan data-data karyawan yang bekerja di kantor KPU yang sudah melakukan absensi dan sudah diinput oleh operator. 


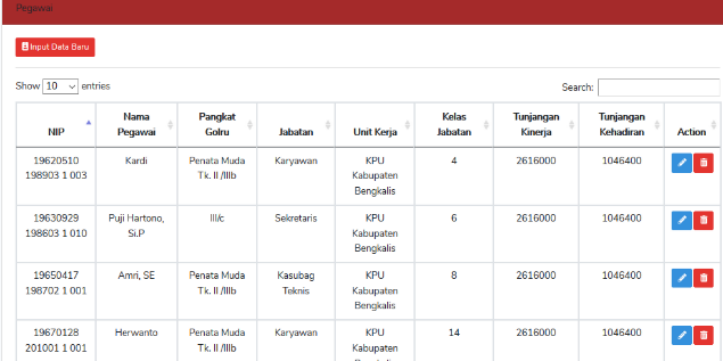

Gbr. 5 Tampilan Menu Pegawai

e. Tampilan menu input pegawai, Tampilan menu input honor terdapat form biodata pegawai yang harus diinput oleh admin, terdiri dari form NIP, Nama Pegawai, Pangkat Golru, Jabatan, Unit Kerja, Kelas Jabatan, Tunjangan Kinerja dan Tunjangan Kehadiran.

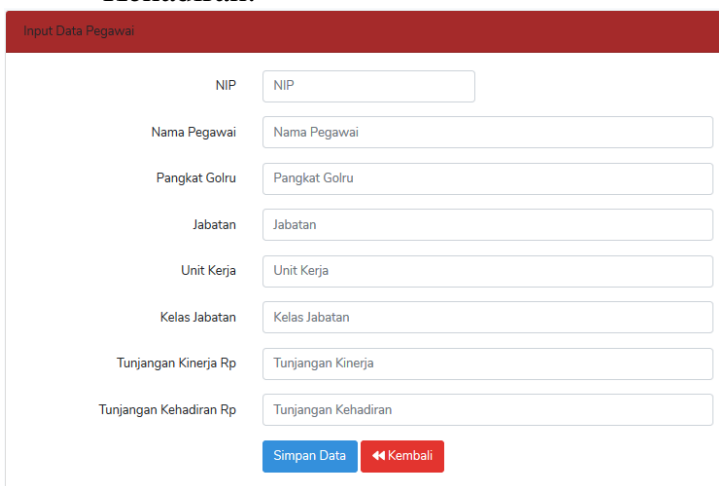

Gbr. 6 Tampilan Menu Input Pegawai

f. Tampilan Menu Absen, Tampilan menu absen ini merupakan tampilan nama- nama keseluruhan karyawan yang bekerja di kantor KPU, baik itu karyawan honor maupun karyawan Pegawai atau disebut dengan PNS.

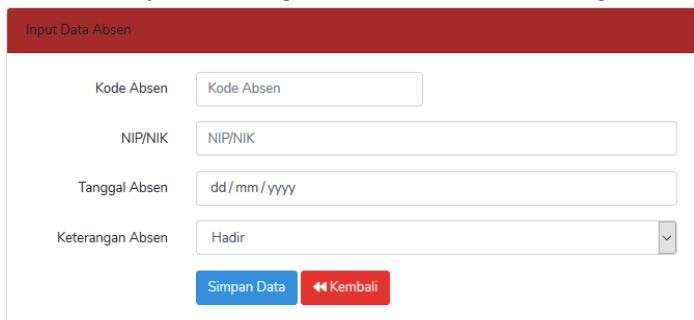

Gbr. 7 Tampilan Menu Absen

g. Tampilan menu rekap absen honorer, Tampilan menu rekap absen honor terdapat form pencarian berdasarkan tanggal untuk mencetak data absen perhari. Sedangkan button cetak hijau untuk mencteak semua data absen honor.

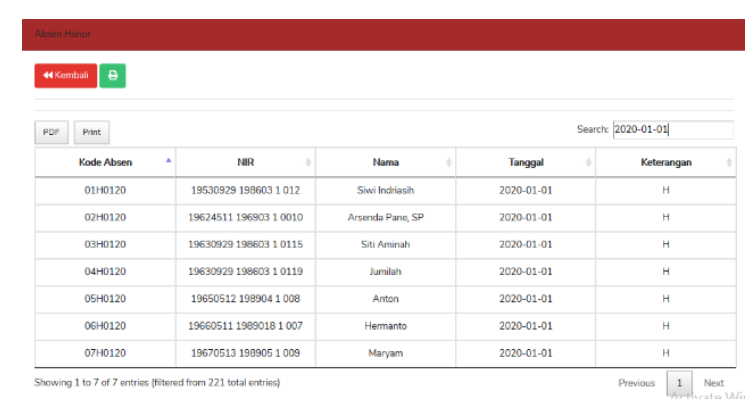

Gbr. 8 Tampilan Menu Absen Honorer Perhari

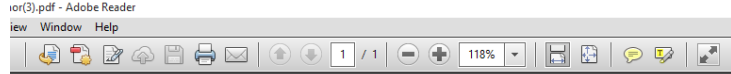

\begin{tabular}{lclll}
\multicolumn{5}{c}{ Absen Honor } \\
\hline Kode Absen & NIR & \multicolumn{1}{c}{ Nama } & Tanggal & Keterangan \\
\hline $01 H 0120$ & 195309291986031012 & Siwi Indriasih & $2020-01-01$ & H \\
02H0120 & 1962451119690310010 & Arsenda Pane, SP & $2020-01-01$ & H \\
03H0120 & 1963092919860310115 & Siti Aminah & $2020-01-01$ & H \\
04H0120 & 1963092919860310119 & Jumilah & $2020-01-01$ & H \\
05H0120 & 196505121989041008 & Anton & $2020-01-01$ & H \\
06H0120 & 1966051119890181007 & Hermanto & $2020-01-01$ & H \\
07H0120 & 196705131989051009 & Maryam & $2020-01-01$ & H
\end{tabular}

Gbr. 9 Tampilan Cetak Absen Honorer

\begin{tabular}{|c|c|c|c|c|}
\hline No & NIP & Nama & Tanggal Absen & Ket Absen \\
\hline 1 & 196505121989041008 & Anton & & $\mathrm{H}$ \\
\hline 2 & 1962451119690310010 & Arsenda Pane, SP & 2020-01-01 & $\mathrm{H}$ \\
\hline 3 & 195309291986031012 & Siwi Indriasih & 2020-01-01 & $\mathrm{H}$ \\
\hline 4 & 1963092919860310115 & Siti Aminah & 2020-01-01 & $\mathrm{H}$ \\
\hline 5 & 1963092919860310119 & Jumilah & 2020-01-01 & $\mathrm{H}$ \\
\hline 6 & 196505121989041008 & Anton & $2020-01-01$ & $\mathrm{H}$ \\
\hline 7 & 1966051119890181007 & Hermanto & 2020-01-01 & $\mathrm{H}$ \\
\hline 8 & 196705131989051009 & Maryam & 2020-01-01 & H \\
\hline 9 & 1962451119690310010 & Arsenda Pane, SP & 2020-01-02 & H \\
\hline 10 & 195309291986031012 & Siwi Indriasih & 2020-01-02 & $\mathrm{H}$ \\
\hline 11 & 1963092919860310115 & Siti Aminah & $2020-01-02$ & $\mathrm{H}$ \\
\hline 12 & 1963092919860310119 & Jumilah & 2020-01-02 & H \\
\hline 13 & 196505121989041008 & Anton & $2020-01-02$ & $\mathrm{H}$ \\
\hline
\end{tabular}

Gbr. 10 Tampilan Cetak Semua Absen Honorer

h. Tampilan menu rekap Absen Pegawai, Tampilan menu rekap absen pegawai terdapat form pencarian berdasarkan tanggal untuk mencetak data absen perhari. Sedangkan button cetak hijau untuk mencteak semua data absen pegawai.

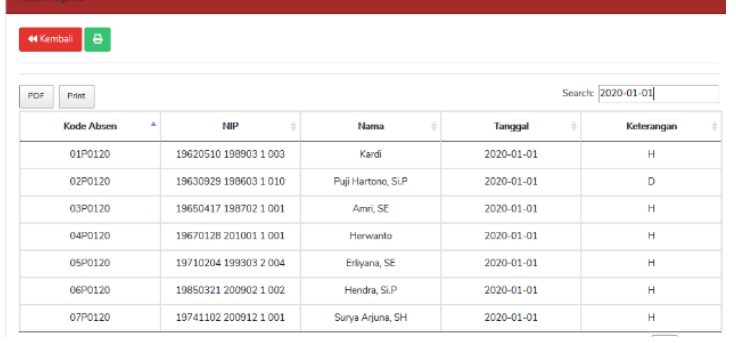

Gbr. 11 Tampilan Menu Absen Pegawai 


\begin{tabular}{lclll}
\multicolumn{4}{c}{ Absen Pegawai } \\
Kode Absen & NIP & \multicolumn{1}{c}{ Nama } & Tanggal & Keterangan \\
O1P0120 & 196205101989031003 & Kardi & $2020-01-01$ & H \\
O2P0120 & 196309291986031010 & Puji Hartono, Si.P & $2020-01-01$ & D \\
O3P0120 & 196504171987021001 & Amri, SE & $2020-01-01$ & H \\
O4P0120 & 196701282010011001 & Herwanto & $2020-01-01$ & H \\
05P0120 & 197102041993032004 & Erliyana, SE & $2020-01-01$ & H \\
O6P0120 & 198503212009021002 & Hendra, Si.P & $2020-01-01$ & H \\
O7P0120 & 197411022009121001 & Surya Arjuna, SH & $2020-01-01$ & H
\end{tabular}

Gbr. 12 Tampilan Cetak Absen Pegawai Perhari

REKAPITULASI : ABSENSI SEKRETARIAT KOMISI PEMILIHAN UMUM KABUPATEN BENGKALIS

\begin{tabular}{|l|l|l|l|l|}
\hline No & NIP & Nama & Tanggal Absen & Ket Absen \\
\hline 1 & 197411022009121001 & Surya Arjuna, SH & $2020-01-01$ & H \\
\hline 2 & 196205101989031003 & Kardi & $2020-01-01$ & H \\
\hline 3 & 196309291986031010 & Puji Hartono, Si.P & $2020-01-01$ & D \\
\hline 4 & 196504171987021001 & Amri, SE & $2020-01-01$ & H \\
\hline 5 & 196701282010011001 & Herwanto & $2020-01-01$ & H \\
\hline 6 & 197102041993032004 & Erliyana, SE & $2020-01-01$ & H \\
\hline 7 & 198503212009021002 & Hendra, Si.P & $2020-01-01$ & H \\
\hline 8 & 197411022009121001 & Surya Arjuna, SH & $2020-01-02$ & H \\
\hline 9 & 196205101989031003 & Kardi & $2020-01-02$ & H \\
\hline 10 & 196309291986031010 & Puji Hartono, Si.P & $2020-01-02$ & D \\
\hline 11 & 196504171987021001 & Amri, SE & $2020-01-02$ & H \\
\hline 12 & 196701282010011001 & Herwanto & $2020-01-02$ & H \\
\hline 13 & 197102041993032004 & Erliyana, SE & $2020-01-02$ & A \\
\hline 14 & 198503212009021002 & Hendra, Si.P & $2020-01-02$ & H \\
\hline
\end{tabular}

Gbr. 13 Tampilan Cetak Semua Absen Pegawai

i. Tampilan menu rekap penggajian Honorer, Tampilan menu rekap penggajian honor terdapat form pencarian berdasarkan Jabatan.

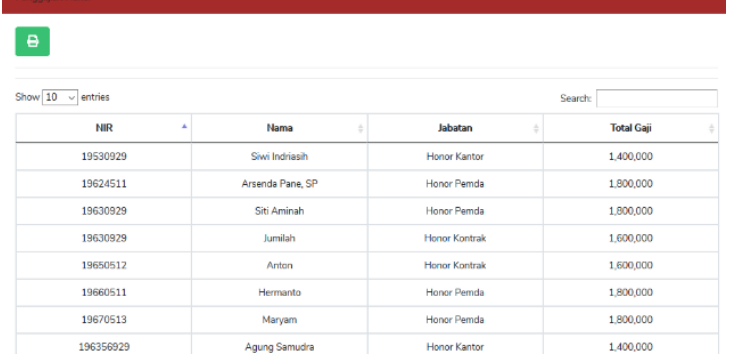

Gbr. 14 Tampilan Menu Penggajian Honorer

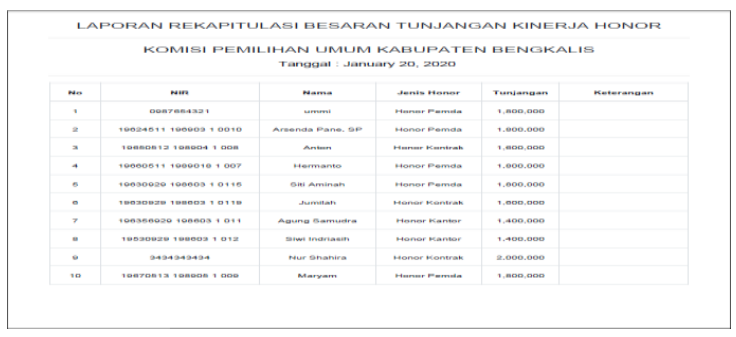

Gbr. 15 Tampilan Cetak Penggajian Honorer

j. Tampilan menu rekap penggajian pegawai, Tampilan menu rekap penggajian pegawai terdapat form pencarian berdasarkan NIP.

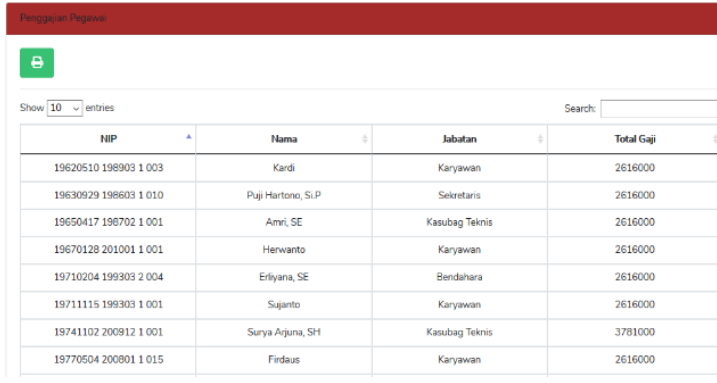

Gbr. 16 Tampilan Menu Penggajian Pegawai

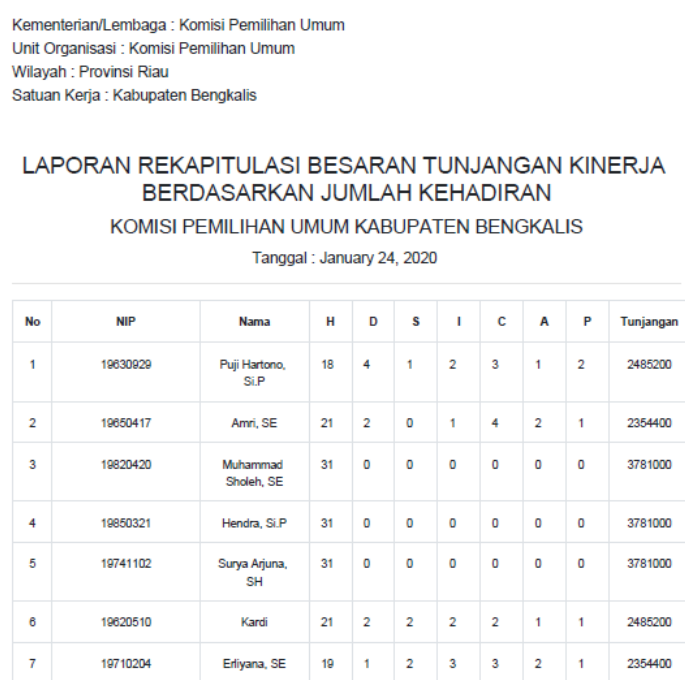

Gbr. 17 Tampilan Cetak Penggajian Pegawai

\section{Pengujian Sistem}

Untuk proses pengujian aplikasi absensi dan penggajian menggunakan uji coba black box yang merupakan teknik pengujian yang berfokus pada spesifikasi fungsional dari perangkat lunak. Aplikasi ini terdiri dari empat panel entri data yaitu Register, Biodata Honor, Biodata Pegawai, dan Absen. Setelah dilakukan pengujian sistem berdasarkan aplikasi di web browser, maka didapatkan hasil pengujian sebagai berikut :

Tabel 1. Hasil Pengujian Sistem Secara

\begin{tabular}{|c|l|c|r|r|}
\hline \multirow{2}{*}{ No } & \multicolumn{1}{|c|}{$\begin{array}{c}\text { Item } \\
\text { Pengujian }\end{array}$} & $\begin{array}{c}\text { Test } \\
\text { Case }\end{array}$ & \multicolumn{2}{|c|}{ Vasil } \\
\cline { 4 - 5 } & $\begin{array}{l}\text { Login admin } \\
\text { pada aplikasi }\end{array}$ & Gbr 1 & $\checkmark$ & Invalid \\
\hline 2 & $\begin{array}{l}\text { Menampilkan } \\
\text { halaman utama }\end{array}$ & Gbr 2 & $\checkmark$ & \\
\hline 3 & $\begin{array}{l}\text { Menampilkan, } \\
\text { menambah, } \\
\text { merubah, dan } \\
\text { menghapus data } \\
\text { honor }\end{array}$ & $\begin{array}{c}\text { Gbr 3 } \\
\text { dan Gbr }\end{array}$ & $\checkmark$ & \\
\hline 4 & $\begin{array}{l}\text { Menampilkan, } \\
\text { menambah, } \\
\text { merubah, dan }\end{array}$ & $\begin{array}{c}\text { Gbr 5 } \\
\text { dan Gbr } \\
6\end{array}$ & $\checkmark$ & \\
\hline
\end{tabular}




\begin{tabular}{|c|l|c|c|c|}
\hline & $\begin{array}{l}\text { menghapus data } \\
\text { pegawai }\end{array}$ & & & \\
\hline 5 & $\begin{array}{l}\text { Menampilkan, } \\
\text { menambah, } \\
\text { merubah, dan } \\
\text { menghapus data } \\
\text { absen }\end{array}$ & $\begin{array}{c}\text { Gbr 7 } \\
\text { dan Gbr } \\
8\end{array}$ & $\checkmark$ & \\
\hline 6 & $\begin{array}{l}\text { Menampilkan } \\
\text { dan mencetak } \\
\text { data rekap } \\
\text { absen honor }\end{array}$ & $\begin{array}{c}\text { Gbr 9, } \\
\text { Gbr 10 Gbr } \\
11\end{array}$ & $\checkmark$ & \\
\hline 7 & $\begin{array}{l}\text { Menampilkan } \\
\text { dan mencetak } \\
\text { data rekap } \\
\text { absen pegawai }\end{array}$ & $\begin{array}{c}\text { Gbr 12 } \\
\text { Gbr 13 Gbr } \\
\text { dan }\end{array}$ & $\checkmark$ & \\
\hline 8 & $\begin{array}{l}\text { Menampilkan } \\
\text { dan mencetak } \\
\text { data penggajian } \\
\text { honor }\end{array}$ & Gbr 15 & & \\
\hline 9 & $\begin{array}{l}\text { Menampilkan } \\
\text { dan mencetak } \\
\text { data penggajian } \\
\text { pegawai }\end{array}$ & Gbr 16 & $\checkmark$ & \\
\hline 10 & $\begin{array}{l}\text { Logout } \\
\text { ogan }\end{array}$ & $\checkmark$ & \\
\hline
\end{tabular}

Sumber : Data Olahan

\section{Kesimpulan}

Dari hasil kerja praktek di Kantor Komisi Pemilihan Umum Kabupaten Bengkalis dapat disimpulkan bahwa Aplikasi Absensi dan Penggajian Pada Kantor KPU menggunakan Framework Laravel adalah aplikasi untuk proses rekap data absensi dan penggajian yang sebelumnya hanya menggunakan cara menandatangani absen yang dikelola admin kemudian admin akan menginput data absen di Microsoft Excel dan merekap gaji perkaryawan, pembuatan aplikasi ini diharapkan dapat mempermudah admin dalam menginput dan merekap data absen dan penggajian yang ada pada Kantor KPU Kabupaten Bengkalis. Aplikasi ini memiliki dua bagian yaitu admin dan karyawan (pegawai dan honorer). Aplikasi Absensi dan Penggajian Pada Kantor KPU dapat melakukan penginputan data pegawai, honorer dan absen yang akan menghasilkan rekap absensi dan penggajian secara berkala (perhari,perbulan dan pertahun).

\section{Referensi}

[1] Firdaus. 2014. Sistem Informasi Akademik (SIA) Sekolah Menengah Kejuruan (SMK) Cendana Padang Panjang dengan Menggunakan Bahasa Pemograman yang Berbasis Object Oriented Programming (OOP) (Studi Kasus SMK Cendana Padang Panjang). Fakultas Ilmu Komputer, Universitas Putra Indonesia YPTK Padang, Padang, Jurnal KOMTEKINFO, Vol. 1, No. 2.

[2] Rahmalisa, U., Irawan, Y., \& Wahyuni, R. (2020). Aplikasi Absensi Guru Pada Sekolah Berbasis Android Dengan Keamanan Qr Code (Studi Kasus: Smp Negeri 4 Batang Gansal). Riau Journal Of Computer Science, 6(2), 135-144.
[3] Harison \& Syarif,Ahmad.(2016).“Sistem Informasi Geografis Sarana Pada Kabupaten Pasaman Barat", Jurnal TEKNOIF, Vol. 4 No. 2 ISSN: 2338-2724. Padang: Institut Teknologi Padang.

[4] Hendini, A. (2016). Pemodelan UML Sistem Informasi Monitoring Penjualan dan Stok Barang (Studi Kasus: Distro Zhezha Pontianak) ade, vol.iv(no.2), 107116.

[5] Jogiyanto. 2015. Partial Least Square (PLS) Alternatif Structural Equation Modeling (SEM) dalam Penelitian Bisnis. Ed.1. Yogyakarta: Andi.

[6] Kadir. 2014. Pengenalan Sistem Informasi Edisi Revisi. Andi.Yogyakarta.

[7] Linarta, A., \& Nurhadi, N. (2018). Sistem Informasi Penjadwalan Bel Sekolah Otomatis Berbasis Microcontroller. JURNAL UNITEK, 11(2), 87-98.Rutan Klas IIB Dumai Berbasis Sms Auto Response (SAR). In Prosiding Seminar Nasional (Vol. 1, No. 1, pp. 150-164).

[8] Rahmalisa, U., \& Muhardi, M. (2019). Penerapan Metode TOPSIS untuk Seleksi Penerima Beasiswa (Studi Kasus: SMAN 2 Tebing Tinggi Timur). Jurnal Teknologi Sistem Informasi dan Aplikasi, 2(1), 31-35.Lestari, G.S dan Novianti, (2018). Rancang Bangun Aplikasi Sistem Absensi Karyawan Pada PT. XYZ, Jurnal Komunikasi, Media dan Informatika, Vol. 7 No. 2 .

[9] Luthfi, F. (2017). Penggunaan Framework Laravel Dalam Rancang Bangun Modul Back-End Artikel Website Bisnisbisnis.ID, Jurnal JISKA, Vol. 2, No.1.

[10] Rahmalisa, U. (2018). APLIKASI INVENTORY BERBASIS WEB MENGGUNAKAN BAHASA PEMOGRAMAN PHP DAN MySQL (STUDI KASUS STIKes HANG TUAH PEKANBARU). Jurnal Ilmu Komputer, 7(2), 51-57.

[11] Linarta, A., \& Nurhadi, N. (2019). Aplikasi Bel Sekolah Otomatis Berbasis Arduino Dilengkapi Dengan Output Suara. Informatika, 10(2), 1-7. 